\title{
Enzymes in Cancer
}

\author{
ASPARAGINASE FROM CHICKEN LIVER
}

\author{
By T. OHNUMA,* F. BERGEL AND R. C. BRAY \\ Chester Beatty Research Institute, Institute of Cancer Research: \\ Royal Cancer Hospital, London, S.W. 3
}

(Received 13 October 1966)

\begin{abstract}
1. A procedure for partial purification of asparaginase from chicken liver is presented. 2. The bulk of the enzyme is located in the soluble fraction of chicken liver. 3. Molecular weights of chicken-liver asparaginase and of the guinea-pig serum enzyme, estimated by gel filtration, were 306000 and 210000 respectively. The Michaelis constants $\left(K_{m}\right)$ at $37^{\circ}$ and $\mathrm{pH} 8.5$ were $6.0 \times 10^{-5} \mathrm{M}$ and $7.2 \times 10^{-5} \mathrm{M}$ respectively. 4. At $50^{\circ}$ the chicken-liver enzyme was moderately stable, some activity being lost by aggregation; in dilute electrolyte solutions the activity rapidly diminished. 5. The anti-lymphoma effect of guinea-pig serum in mice carrying the 6C3HED tumour was confirmed. Chicken-liver asparaginase also showed an effect but in this case the enzyme preparation had to be administered repeatedly. 6. Guinea-pig serum asparaginase was stable for several days in mouse blood, after intraperitoneal injection, whereas chicken-liver asparaginase rapidly disappeared. 7. Aspartic acid $\beta$-hydrazide was shown to be a competitive inhibitor of chicken-liver asparaginase with $K_{i}$ approx. $5 \cdot 6 \times 10^{-4} \mathrm{M}$. In mice it produced an anti-lymphoma effect, as reported previously.
\end{abstract}

Inhibition of transplantable lymphomas in mice and rats (Kidd 1953a,b; Jameson, Ainis \& Ryan, 1956, 1958; Kwak, Jameson, Ryan \& Kurtz, 1961; Herbert, Kraemer \& Pillemer, 1958; Ainis et al. 1958) and of spontaneous, radiation-induced and urethane-induced leukaemias in mice (Boyse, Old \& Stockert, 1963 ; G. C. Stock, personal communication) by guinea-pig serum has been observed by several investigators. Broome (1961, 1963a,b) suggested that asparaginase (L-asparagine amidohydrolase EC 3.5.1.1) is the anti-lymphoma factor of guinea-pig serum. Other investigators confirmed this, by using partially purified asparaginase from guinea-pig serum (Mashburn \& Wriston, 1963; Campbell, Old \& Boyse, 1964; Suld \& Hubert, 1965). Recently the homogeneous enzyme from this source has also been found effective (Yellin \& Wriston, 1966). On the other hand asparaginase fractions obtained from sources other than guinea-pig serum were not uniformly active as anti-lymphoma agents. Thus Mashburn \& Wriston (1964) reported that the Escherichia coli enzyme had an anti-lymphoma effect but the enzyme from Bacillus coagulans had no such tumour-inhibitory effect. Suld \& Hubert (1965) reported that 2-3 times as much guinea-pig liver asparaginase was required to obtain the same

\footnotetext{
* Present address: Department of Medicine, Tohoku University School of Medicine, Sendai, Japan.
}

effect compared with guinea-pig serum asparaginase. Since the present work (Ohnuma, 1965) was completed, Broome (1965) has reported the lack of biological effectiveness of purified yeast asparaginase and related this to very rapid clearance of this enzyme from the blood after injecton.

The present paper is devoted to the purification of an asparaginase from chicken liver and to a comparative study of some of its biochemical and biological properties.

\section{MATERIALS AND METHODS}

Materials. All chemicals were A.R. grade unless otherwise stated and glass-distilled water was used throughout. Buffers were prepared according to the Tables of Gomori (1955). The sources of other materials were as follows: L-asparagine monohydrate, British Drug Houses Ltd., (Poole, Dorset); aspartic acid $\beta$-hydrazide was prepared by Dr R. Wade according to Roper \& Mcllwain (1948); calcium phosphate gel was prepared as described by Singer \& Kearney (1950); cytochrome c, Nutritional Biochemicals Corp. (Cleveland, Ohio, U.S.A.); reduced glutathione, Sigma Chemical Co. (St Louis, Mo., U.S.A.); glyceraldehyde 3-phosphate dehydrogenase, C. F. Boehringer und Soehne G.m.b.H. (Mannheim, Germany); DEAE-Sephadex A-50, Pharmacia (Uppsala, Sweden); xanthine oxidase was prepared by Mrs A. Chisholm by the method of Gilbert \& Bergel (1964); $E$. coli extracts, Research Department, Glaxo Ltd. (Greenford, Middlesex); Ringer solution, Allen and Hanbury Ltd. (London, W. 1). 
Guinea-pig serum asparaginase. All experiments were carried out with guinea-pig serum without purification. It was obtained from adult animals of random breed and either sex maintained at the Chester Beatty Research Institute. The serum was kept frozen at $-40^{\circ}$. A part of the work was carried out with 'guinea-pig serum complement' (Burroughs Wellcome Ltd., Beckenham, Kent), which had specific activity approx. $80 \%$ of that of fresh preparations. However, this was more toxic towards mice than were the fresh preparations. The enzyme activity was measured with each lot of serum.

Assay of asparaginase. Asparaginase was assayed by a method described by Meister, Levintow, Greenfield \& Abendschein (1955) with a minor modification. The reaction mixture consisted of $0.5 \mathrm{ml}$. of $40 \mathrm{mM}$-L-asparaginase monohydrate, $1.0 \mathrm{ml}$. of $0.1 \mathrm{M}$-sodium borate buffer, $\mathrm{pH} 8.5$, and $0.5 \mathrm{ml}$. of appropriately diluted enzyme. The reaction tubes were incubated at $37^{\circ}$, usually for $1 \mathrm{hr}$. At the end of incubation $0.5 \mathrm{ml}$. of cold $15 \%(\mathrm{w} / \mathrm{v})$ trichloroacetic acid was added, the mixture was centrifuged, and $1 \mathrm{ml}$. of supernatant was used for the ammonia determination. Each ammonia determination was supplemented by a parallel assay of ammonia as internal standard [0.4 $\mu$ mole/ reaction tube, as $\left.\left(\mathrm{NH}_{4}\right)_{2} \mathrm{SO}_{4}\right]$. The sensitivity of the method was not great enough to measure true initial velocities at low substrate concentrations. Consequently, when values of $K_{m}$ were determined it was necessary to average the initial and final substrate concentrations. Generally the corrections were small, but at the lowest substrate concentration as much as $50 \%$ of the substrate had to be deaminated before sufficient ammonia was present to allow accurate estimations.

Ammonia was determined by Russel's (1944) phenolhypochlorite reaction modified by Konitzer \& Voigt (1963). One unit of asparaginase activity was defined as the number of $\mu$ moles of ammonia liberated $/ \mathrm{min}$. at $37^{\circ}$ and at $\mathrm{pH} 8.5$. Total activity is expressed as the number of units $/ \mathrm{kg}$. of wet liver. The specific activity of the preparation at any stage during the preparation procedure is expressed as the number of units/mg. of protein.

Preliminary study of the enzyme assay showed that the maximum blue colour developed in $30 \mathrm{~min}$. at room temperature was stable at least for another hour, as measured at $635 \mathrm{~m} \mu$. When the tubes were placed in a warm-water bath the colour developed more rapidly, but was less stable. The extinction of the fully developed colour was proportional to the ammonia concentration up to $1.38 \mu \mathrm{moles}$ of ammonia/ml. of original supernatant, corresponding to an extinction ( $1 \mathrm{~cm}$. light-path) of $4 \cdot 6$; the maximum extinction attainable was $6 \cdot 0$. The extinction was also proportional to enzyme concentration, for fixed incubation periods; constant rates of ammonia formation for at least $2 \mathrm{hr}$. were obtainable. The method is sensitive and as little as $0.01 \mu$ mole of ammonia can be measured reproducibly. As the concentration of substrate, L-asparagine, in the reaction mixture is increased the density of the blue colour decreases, but with the substrate concentrations used the decrease was less than $2 \%$ of a control containing no asparagine. Addition of ammonia in the form of $\left(\mathrm{NH}_{4}\right)_{2} \mathrm{SO}_{4}$ as an internal standard did not influence the linearity between the colour density and asparaginase activity as long as the final extinction was below $4 \cdot 6$.

The effect of aspartic acid hydrazide on asparaginase activity was measured as follows. The reaction mixture consisted of $0.5 \mathrm{ml}$. of $0.8 \mathrm{mM}$ - or $20 \mathrm{mM}$-asparagine, $0.5 \mathrm{ml}$. of 20 -fold diluted guinea-pig serum and $0.5 \mathrm{ml}$. of $0.1 \mathrm{M}$ borate buffer, $\mathrm{pH} 8 \cdot 8$. To this was added $0.5 \mathrm{ml}$. of aspartic acid $\beta$-hydrazide to give final concentrations in the range 2.5-7.5 mM. Since the presence of either asparagine or aspartic acid hydrazide caused a decrease of the blue colour in the ammonia determination, appropriate internal standards were used with each set of reaction mixtures. The average substrate concentration was calculated as described above.

Asparaginase activities in mouse plasma. Partially purified chicken-liver enzyme (1 ml., $2 \cdot 3$ units $/ \mathrm{ml}$.) was injected intraperitoneally into six mice. After certain time intervals approx. $100 \mu$ l. of blood was obtained from two or three mice in rotation by puncture of the ocular venous plexus with glass capillary tubes. One end of the tube was sealed with a flame and the erythrocytes were sedimented by centrifugation. Then $10 \mu$ l. of supernatant plasma was added to each of the tubes containing frozen assay mixture. The tubes with assay mixture and plasma were kept frozen until the end of the experiment. The incubation period had to be prolonged to $2 \mathrm{hr}$. to increase the sensitivity of the assay. An identical experiment was performed with guinea-pig serum as the source of asparaginase.

Assay of other enzymes. Cytochrome oxidase was measured as described by Applemans, Wattiaux \& de Duve (1955), xanthine oxidase by the method of Bergel \& Bray (1959) and glyceraldehyde phosphate dehydrogenase by a method described by Wu \& Racker (1959).

Assay of protein. Most of the protein determinations were carried out by a micro-Kjeldahl method, with the apparatus of Markham (1942). With more highly purified preparations, when the samples were clear, protein concentration was determined from extinction measurements at 260 and 280 $\mathrm{m} \mu$, according to the method of Warburg \& Christian (1942).

Cell particle fractionation. This was carried out by a method of de Duve, Pressman, Gianetto, Wattiaux \& Applemans (1955) and the distribution pattern of cytochrome oxidase was used as a marker of each fraction.

Sephadex G-200 columns. Dry Sephadex G-200 powder was first sieved to remove particles smaller than 300 mesh, stirred into 0.01 M-sodium phosphate buffer, pH 7.4, containing $0.1 \mathrm{M}-\mathrm{KCl}$ and stood at room temperature for 4-5days. The buffer was changed several times by sedimentation and decantation to remove fine particles. The Sephadex suspension was evacuated to remove dissolved gases before packing the column, and the gel slurry was introduced in a steady stream directly into the tube filled with buffer. For preparative work upward flow was used and the column tube was made from Perspex $(5 \mathrm{~cm}$. diam. $\times 80 \mathrm{~cm}$. long). The column bottom was made from porous polythene. The column top had a similar design to the bottom but had a sliding height adaptor. Both column ends had two narrow-bore outlet holes. This column has minimum dead spaces and showed excellent performance for upward-flow gel filtration. For molecular-weight determinations a downward-flow column (diam. $2 \cdot 1 \mathrm{~cm}$.) was used. The height of the Sephadex varied from 48 to $49.5 \mathrm{~cm}$. Effluent was collected in $3 \mathrm{ml}$. fractions at a rate of $12 \mathrm{ml}$. $/ \mathrm{hr}$.

Animals. Adult female mice of CBA strain bred at the Chester Beatty Research Institute were used. Groups of six mice were kept in one cage and maintained on rat cube diet supplemented with maize. Water was given ad libitum. Tumour cells. Cells of mouse lymphoma 6C3HED, 
originally obtained from Dr J. D. Broome, were serially transplanted into CBA mice at the Chester Beatty Research Institute. During the transplantation for at least 40 generations in a total of $120 \mathrm{CBA}$ mice no spontaneous regression of the tumour was observed. The methods of implantation were essentially the same as those described by Broome (1963a). The cell suspension was diluted so that $1 \mathrm{ml}$. contained $5 \times 10^{5}$ or $10^{6}$ viable cells, and $0.2 \mathrm{ml}$. was injected into each groin (i.e. $\mathbf{0 . 4 \mathrm { ml }}$./mouse). Amounts and schedules of the various treatments are described in the Tables. In every experiment all the animals were examined daily after implantation. All mice were killed on appropriate dates and tumours were excised and weighed.

\section{RESULTS}

Asparaginase in livers of various species. The enzyme activities of homogenates of liver from species that are commercially available in large quantities were studied in comparison with liver homogenates of laboratory animals and guinea-pig serum. The results are shown in Table 1 . The results encouraged the use of chicken liver for the

Table 1. Asparaginase activity in the livers of various species, in guinea-pig serum and in E. coli

\begin{tabular}{|c|c|c|c|}
\hline Species & $\begin{array}{l}\text { No. of } \\
\text { samples } \\
\text { studied }\end{array}$ & $\begin{array}{c}\text { Total } \\
\text { activity } \\
\text { (units/kg. of } \\
\text { liver) }\end{array}$ & $\begin{array}{c}\text { Specific } \\
\text { activity } \\
\text { (milliunits/mg. } \\
\text { of protein) }\end{array}$ \\
\hline Guinea pig & 1 & 2870 & $15 \cdot 1$ \\
\hline Rat & 1 & 1860 & $10 \cdot 1$ \\
\hline Chicken & 2 & $\begin{array}{l}1415 \\
2280\end{array}$ & $\overline{12 \cdot 0}$ \\
\hline Mouse (CBA) & 1 & 1720 & $9 \cdot 3$ \\
\hline Rabbit & 1 & 990 & $6 \cdot 02$ \\
\hline $\mathrm{Ox}$ & 1 & 530 & 3.31 \\
\hline Pig & 5 & $\begin{array}{c}\text { 123-284 } \\
\text { (av. 194) }\end{array}$ & $\begin{array}{r}0.70-1.90 \\
(\text { av. } 1.21)\end{array}$ \\
\hline $\begin{array}{l}\text { Guinea-pig } \\
\text { serum }\end{array}$ & 3 & $\begin{array}{l}1980^{*} \\
2370^{*} \\
2960^{*}\end{array}$ & $\frac{38 \cdot 4}{57 \cdot 2}$ \\
\hline E. coli $\uparrow$ & 1 & - & $49 \cdot 0$ \\
\hline
\end{tabular}

further studies. On investigation of the intracellular distribution of the chicken-liver enzyme it was found that more than $86 \%$ of the activity was present in the soluble fraction.

Preparation of the enzyme from chicken liver. The various steps of the purification procedure finally adopted are shown with summarizing data in Table 2. Many steps commonly employed for enzyme isolations were inapplicable. Thus attempts at $\mathrm{pH}$ fractionation revealed that almost all activity was precipitated at $\mathrm{pH} 5$, but the precipitated material did not redissolve again at $\mathrm{pH} 7 \cdot 4$. Though part of the activity was recovered when the $\mathrm{pH}$ fractionation was done in hyperosmotic solution (2M-potassium chloride), no purification was achieved. The enzyme activity was also destroyed by organic solvents. Exposure of the chicken-liver enzyme to butan-1-ol or acetone-propan-1-olacetic acid mixture (Euler, 1961) resulted in almost complete loss of activity. Studies on fractional denaturation by heat showed that activity was precipitated before it was destroyed (see below). DEAE-Sephadex column chromatography could not be employed successfully, owing to the low stability of the enzyme at low salt concentrations.

Purification procedure. Step 1. Chicken livers were removed at a commercial slaughterhouse and packed in ice. They were homogenized with an MSE Ato-Mix homogenizer (three runs of 20 sec. at full speed) in twice their volume of $0.01 \mathrm{M}$-sodium

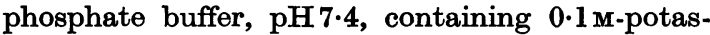
sium chloride. All subsequent operations were carried out between 0 and $4^{\circ}$ unless otherwise stated. The homogenate was centrifuged at $41000 \mathrm{~g}$ for $15 \mathrm{~min}$., yielding a clear red supernatant.

Step 2. To the crude supernatant (approx. $500-600 \mathrm{ml}$.) was added, with constant stirring, solid sodium sulphate decahydrate $(36.7 \mathrm{~g} . / 100 \mathrm{ml}$. of solution) to give a $33 \%(w / v)$ salt solution. It was necessary to elevate the temperature of the sample solution because solid sodium sulphate decahydrate is relatively insoluble in the cold, but the maximum temperature was kept below $37^{\circ}$, when loss of the enzyme activity remains minimal (see below and Fig. 2).

After the salt was completely dissolved the

Table 2. Summary of the purification of asparaginase from chicken liver

\begin{tabular}{|c|c|c|c|c|}
\hline & $\begin{array}{c}\text { Total activity } \\
\text { (units/kg. of liver) }\end{array}$ & $\begin{array}{l}\text { Specific activity } \\
\text { (milliunits/mg. } \\
\text { of protein) }\end{array}$ & $\begin{array}{c}\text { Yield } \\
(\%)\end{array}$ & Purification \\
\hline Crude homogenate & 1165 & 一 & $(100)$ & - \\
\hline Crude supernatant & 850 & $11 \cdot 9$ & $73 \cdot 5$ & 1 \\
\hline Sodium sulphate precipitate & 628 & $18 \cdot 5$ & $54 \cdot 2$ & 1.55 \\
\hline Pooled fractions from Sephadex chromatography & 405 & $66 \cdot 2$ & $35 \cdot 0$ & $5 \cdot 58$ \\
\hline Adsorbed on calcium phosphate eluted with borax & 103 & 82 & $8 \cdot 9$ & 6.9 \\
\hline
\end{tabular}


solution was left at room temperature for about $15 \mathrm{~min}$., centrifuged at $10000 \mathrm{~g}$ for $15 \mathrm{~min}$., and the supernatant filtered through gauze to remove a small amount of floating fatty material. Further solid sodium sulphate decahydrate $(42 \cdot 6 \mathrm{~g} . / 100 \mathrm{ml}$.) was added to give a $58 \%(w / v)$ salt solution. The resulting precipitate was separated by centrifugation and dissolved in a small volume of the buffer used in step 1 .

Step 3. The same buffer was used for dialysing the sample solution before it was applied to a column $(80 \mathrm{~cm} . \times 5 \mathrm{~cm}$.) of Sephadex G-200. A $100-150 \mathrm{ml}$. sample of the solution was chromatographed at a time, and the effluent was collected in $10 \mathrm{ml}$. fractions at a flow rate of $30 \mathrm{ml} . / \mathrm{hr}$. The active fractions were pooled, the enzyme was precipitated by $80 \%$-saturated ammonium sulphate, dialysed in Ringer solution, and the sample concentrated by vacuum dialysis. Some of the material was used at this stage for the biological experiments.

Step 4. The pooled active fractions after column chromatography on Sephadex were used for fractional adsorption on calcium phosphate gel. The solution was diluted so that the concentration of the protein was less than $10 \mathrm{mg} . / \mathrm{ml}$. For each $1 \mathrm{~g}$. of protein approx. $2 \mathrm{~g}$. of the gel was used, which adsorbed the enzyme protein satisfactorily. The gel-protein mixture was washed four or five times with 0.01M-sodium phosphate buffer, $\mathrm{pH} 7.4$, containing $0 \cdot 1 \mathrm{~m}$-potassium chloride. The protein was then eluted by washing in borax solutions up to $0.15 \mathrm{M}$. The eluate was centrifuged to remove any residual gel and dialysed in the usual buffer.

For smaller batches of chicken liver the purification procedure, with minor modifications such as interchanging steps 2 and 3, gave results rather better than those recorded in Table 2 with up to 15-fold purification, up to $24 \%$ recovery of activity and specific activities up to 99 milliunits/mg. were obtained.

Molecular weight. This was determined by gel filtration on Sephadex G-200 by the method of Andrews (1965) and Andrews, Bray, Edwards \& Shooter (1964). Partially purified chicken-liver enzyme was mixed with marker enzymes, i.e. xanthine oxidase and glyceraldehyde 3-phosphate dehydrogenase, and placed on a column of Sephadex G-200. The elution volume of glyceraldehyde 3-phosphate dehydrogenase was $109 \mathrm{ml}$. (mol. wt. 120000 ), that of xanthine oxidase $87 \mathrm{ml}$. (mol. wt. 275000) and that of chicken-liver asparaginase $83 \mathrm{ml}$. The position of the peak of the chicken-liver enzyme thus indicates mol. wt. 306000. A similar experiment was carried out with guinea-pig serum asparaginase and the mol. wt. was calculated to be 210000. An experiment with the $E$. coli extract indicated two active components, the major one having mol. wt. about 900000 or higher and the minor one mol. wt. about 140000.

Michaelis constants. The activity of chicken-liver asparaginase as a function of substrate concentration is illustrated in Fig. 1. A similar experiment was carried out with guinea-pig serum asparaginase. $K_{m}$ values of the chicken-liver and guinea-pig serum enzymes at pH 8.5 in 0.1 $\mathrm{M}$-borate buffer were found to be similar, namely $6.0 \times 10^{-5} \mathrm{M}$ for the avian enzyme and $7 \cdot 2 \times 10^{-5} \mathrm{M}$ for the mammalian enzyme.

Stability of the chicken-liver enzyme. Fig. 2 illustrates the stability of the enzyme after heat treatment (15 min. at the indicated temperature). At $50^{\circ}$ only $30 \%$ of the activity was destroyed but the

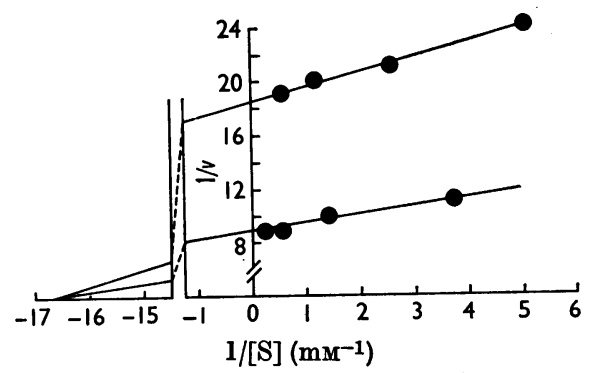

Fig. 1. Lineweaver-Burk plot for chicken-liver asparaginase at two enzyme concentrations. Measurements were made at $37^{\circ}$ in $0.1 \mathrm{~m}$-borate buffer, $\mathrm{pH} 8.5$. The velocity of asparagine deamination is expressed as $\mu$ moles of $\mathrm{NH}_{3}$ liberated/ min.

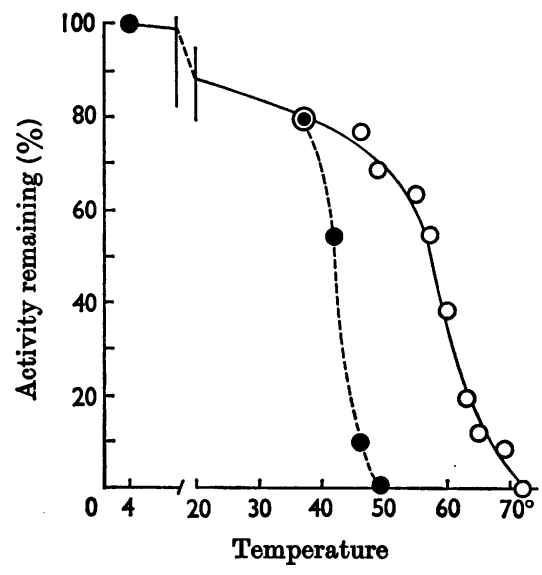

Fig. 2. Effect of temperature on the stability of chickenliver asparaginase. Samples of the enzyme (step 1 of purification) in $0 \cdot 1 \mathrm{M}-\mathrm{KCl}$ containing $0.01 \mathrm{M}$-sodium phosphate buffer, $\mathrm{pH} 7 \cdot 4$, were heated for $15 \mathrm{~min}$. at the temperatures shown. -..-., Activity measured on $4000 \mathrm{~g}$ supernatant after heat treatment; -, activity measured on uncentrifuged suspension after heat treatment. 
Table 3. Effect of electrolyte concentration on the stability of chicken-liver asparaginase

Samples of the enzyme were dialysed for $16 \mathrm{hr}$. against 2000 vol. of the solutions indicated, at $3^{\circ}$, and then assayed.

\begin{tabular}{|c|c|c|c|c|}
\hline $\mathrm{pH}$ & Buffer & Salts & Additives & $\begin{array}{l}\% \text { of initial } \\
\text { activity }\end{array}$ \\
\hline $7 \cdot 4$ & Sodium phosphate $(0.01 \mathrm{~m})$ & $\mathrm{KCl}(0.1 \mathrm{M})$ & - & 100 \\
\hline $\mathbf{7 \cdot 4}$ & Sodium phosphate $(0.001 \mathrm{M})$ & - & - & $4 \cdot 35$ \\
\hline $\mathbf{7 \cdot 4}$ & Sodium phosphate $(0.001 \mathrm{M})$ & - & GSH $(20 \mu \mathrm{M})$ & 4.55 \\
\hline $\mathbf{7 \cdot 4}$ & Sodium phosphate $(0.001 \mathrm{M})$ & - & EDTA $(0.001 \mathrm{M})$ & $12 \cdot 9$ \\
\hline $\mathbf{7 \cdot 4}$ & Potassium phosphate $(0.001 \mathrm{M})$ & - & - & $10 \cdot 0$ \\
\hline $\mathbf{7 \cdot 4}$ & Sodium phosphate $(0.01 \mathrm{M})$ & - & - & $30 \cdot 3$ \\
\hline $\mathbf{7 \cdot 4}$ & Tris-HCl $(0.01 \mathrm{M})$ & - & - & $11 \cdot 0$ \\
\hline $\mathbf{7 \cdot 4}$ & Sodium phosphate $(0.01 \mathrm{M})$ & Arsenate (2 $\mathrm{mM})$ & Salicylate (1 mM) & 10.8 \\
\hline $8 \cdot 8$ & Borate $(0.02 \mathrm{M})$ & $\mathrm{KCl}(0.02 \mathrm{M})$ & - & $16 \cdot 8$ \\
\hline $8 \cdot 0$ & Sodium phosphate $(0.02 \mathrm{M})$ & $\mathrm{KCl}(0.02 \mathrm{M})$ & - & $42 \cdot 5$ \\
\hline $8 \cdot 0$ & Sodium phosphate $(0.02 \mathrm{M})$ & $\mathrm{KCl}(0.05 \mathrm{M})$ & - & $76 \cdot 5$ \\
\hline $8 \cdot 0$ & Sodium phosphate $(0.02 \mathrm{M})$ & $\mathrm{KCl}(0.1 \mathrm{M})$ & - & 100 \\
\hline $\mathbf{7 \cdot 4}$ & Sodium phosphate $(0.001 \mathrm{M})$ & - & - & \\
\hline $7 \cdot 4$ & $\begin{array}{l}\text { then } \\
\text { Sodium phosphate }(0.01 \mathrm{M})\end{array}$ & $\mathrm{KCl}(0.1 \mathrm{M})$ & - & $\mathbf{0}$ \\
\hline
\end{tabular}

Table 4. Anti-lymphoma effects

Each mouse received $10^{5} 6 \mathrm{C} 3 \mathrm{HED}$ cells in each bilateral groin, the day before treatment commenced. All injections were intraperitoneal. In Experiment A, groups 5-8 received 2\% (w/v) of L-asparagine added to their drinking water. AGPS, guinea-pig serum asparaginase; ACL, chicken-liver asparaginase.

\begin{tabular}{|c|c|c|c|c|c|c|c|c|}
\hline Expt. & Group & $\begin{array}{l}\text { No. of } \\
\text { mice }\end{array}$ & Treatment & $\begin{array}{l}\text { Total dose } \\
\text { (units/mouse) }\end{array}$ & Schedule & $\begin{array}{l}\text { No. of } \\
\text { days }\end{array}$ & $\begin{array}{c}\text { Average } \\
\text { body } \\
\text { wt. } \\
\text { change } \\
(\%)\end{array}$ & $\begin{array}{c}\text { Average } \\
\text { tumour } \\
\text { wt. } \\
\text { (土 s.E.M.) }\end{array}$ \\
\hline $\mathbf{A}$ & 1 & 4 & - & - & - & 12 & +31 & $3.2( \pm 0.2)$ \\
\hline $\mathbf{A}$ & 2 & 4 & AGPS & 0.5 & Single injection & 12 & +20 & $1.6( \pm 0.2)$ \\
\hline $\mathbf{A}$ & 3 & 4 & AGPS & 0.9 & Single injection & 12 & +16 & $1.0( \pm 0.5)$ \\
\hline $\mathbf{A}$ & 4 & $\begin{array}{c}4 \\
(1 \text { died })^{*}\end{array}$ & AGPS & 1.9 & Single injection & 12 & +3 & $0.1( \pm 0.1)$ \\
\hline $\mathbf{A}$ & 5 & 3 & Asparagine & - & - & 12 & +30 & $2.9( \pm 0.4)$ \\
\hline $\mathbf{A}$ & 6 & 4 & Asparagine, AGPS & 0.5 & Single injection & 12 & +27 & $2.4( \pm 0.2)$ \\
\hline $\mathbf{A}$ & 7 & 4 & Asparagine, AGPS & 0.9 & Single injection & 12 & +28 & $2 \cdot 1( \pm 0.2)$ \\
\hline $\mathbf{A}$ & 8 & $\stackrel{4}{4}$ & Asparagine, AGPS & 1.9 & Single injection & 12 & +8 & $0.9( \pm 0.2)$ \\
\hline B & 1 & 5 & - & - & - & 15 & +20 & $5.9( \pm 0.4)$ \\
\hline B & 2 & 7 & ACL & 0.7 or 1.0 & Single injection & 15 & +11 & $5 \cdot 1( \pm 0 \cdot 6)$ \\
\hline B & 3 & 6 & ACL & $6 \cdot 1$ & $\begin{array}{l}7 \text { injections at } 20 \mathrm{hr} . \\
\text { intervals }\end{array}$ & 15 & +16 & $3.9( \pm 0.3)$ \\
\hline B & 4 & 4 & Heated ACL & $(6 \cdot 1)$ & $\begin{array}{l}7 \text { injections at } 20 \mathrm{hr} \text {. } \\
\text { intervals }\end{array}$ & 15 & +17 & $5 \cdot 6( \pm 0 \cdot 8)$ \\
\hline C & 1 & 4 & - & - & - & 12 & +3 & $3 \cdot 1( \pm 0 \cdot 3)$ \\
\hline C & 2 & .3 & Aspartic hydrazide & $4.5 \mathrm{mg}$. & $\begin{array}{l}8 \text { injections at } 24 \mathrm{hr} \text {. } \\
\text { intervals }\end{array}$ & 12 & +4 & $2 \cdot 0( \pm 0.2)$ \\
\hline
\end{tabular}

* Deaths at this dose of AGPS were observed with the Burroughs Wellcome Ltd. serum, but there were none if fresh serum was substituted.

activity was in the form of a heat coagulate, precipitable by centrifugation. These results suggest that the enzyme is adsorbed on heat-inactivated protein. Stability tests $\left(15 \mathrm{~min}\right.$. at $46^{\circ}$ or $\left.60^{\circ}\right)$ of the enzyme in buffer solutions $(0.05 \mathrm{M})$ ranging from pH 4 to pH 10 showed that the activity was uniformly diminished at all $\mathrm{pH}$ values.
The enzyme was inactivated, apparently irreversibly, when dialysed against dilute buffers. Glutathione $(20 \mu \mathrm{M})$, EDTA (1 mM), arsenate (2mM) and sodium salicylate (1 mM) failed to prevent inactivation (see Table 3).

Inhibition by aspartic acid $\beta$-hydrazide. Experiments with this hydrazide were plotted as described 
by Dixon \& Webb (1964). Inhibition was found to be competitive with $K_{t} 5 \cdot 6 \times 10^{-4} \mathrm{M}$.

Anti-lymphoma effect of chicken-liver asparaginase, of guinea-pig serum and of aspartic acid $\beta$-hydrazide. The results of tumour-inhibitory tests of chickenliver asparaginase preparations and of guinea-pig serum asparaginase are recorded in Table 4, in three separate experiments. In the first, the effects of single injections of various amounts of guinea-pig serum asparaginase (A2-A4) are compared with controls (Al). The experiment was repeated (A5-A8) with the mice receiving, in addition to the enzyme, $2 \%(\mathrm{w} / \mathrm{v})$ L-asparagine in their drinking water. As can be seen from the tumour weights the guinea-pig serum asparaginase was highly effective as compared with controls. Asparagine decreased this effect, thus providing direct evidence for the asparaginase acting in vivo by destroying the essential amino acid. [Broome (1963b) did not demonstrate such antagonism between the enzyme and its substrate. However, this was almost certainly due to the fact that, under his conditions, as discussed in the next section, the injected enzyme would survive for a long period, while the substrate would probably have been rapidly cleared.]

Single doses of chicken-liver asparaginase (0.71.0 unit) failed to inhibit the tumours (B2), whereas at this same dose guinea-pig serum asparaginase was effective (A3). In another experiment, not recorded in Table 4, 2.2 units of chicken-liver asparaginase were also not effective. Repeated doses of chicken-liver asparaginase (B3) produced some effect when compared with controls (B1) or with repeated injections of heat-denatured enzyme (B4). Experiment C2, reporting the effects of aspartic acid $\beta$-hydrazide, confirmed the partial tumour inhibition by this compound as reported by Michelson \& Flippin (1958).

Plasma asparaginase activities after administration of chicken-liver asparaginase and guinea-pig serum asparaginase. To elucidate the inactivity of

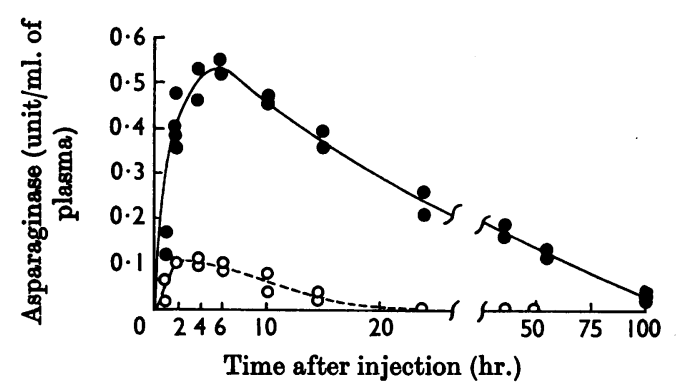

Fig. 3. Plasma asparaginase activities after intraperitoneal injection. ๑, Guinea-pig serum asparaginase (2.1 units); $O$, chicken-liver asparaginase $(2 \cdot 3$ units). single injections of chicken-liver asparaginase against the mouse lymphoma, plasma asparaginase activities after intraperitoneal injections of the enzyme into mice were measured. Fig. 3 illustrates the activities of chicken-liver asparaginase and guinea-pig serum asparaginase after a single injection.

With guinea-pig serum asparaginase the activity becomes measurable almost immediately after the injection and reaches a maximum in $6 \mathrm{hr}$. The enzyme activity persisted for a considerable period and the half-life was approx. $20 \mathrm{hr}$. After $100 \mathrm{hr}$. appreciable activity could still be detected. Very similar results have been published by Broome (1965). In contrast, when a similar amount of chicken-liver asparaginase was administered the peak activity, reached in $2-3 \mathrm{hr}$., was less than $20 \%$ of that with guinea-pig serum asparaginase and the activity became undetectable in $20 \mathrm{hr}$. The difference in the total integration (enzyme activity $\times$ time) was 16.5-fold.

\section{DISCUSSION}

Asparaginase was first discovered in animal tissues by Lang (1904) and in fungi by Shibata (1904). Subsequent studies indicated that its occurrence is widespread (see Kretovich, 1958). Owing to an unusually high content of the enzyme in guinea-pig serum (Clementi, 1922) this has been used successfully as a starting material by many workers (Meister et al. 1955; Broome, $1963 a$; Tower, Peters \& Curtis, 1963; Mashburn \& Wriston, 1963; Suld \& Hubert, 1965; Yellin \& Wriston, 1966). The enzyme has also been partially purified from bacteria (Manning \& Campbell, 1957; Mashburn \& Wriston, 1964) and yeast (Goddes \& Hunter, 1928; Grassman \& Mayr, 1933; Broome, 1965). Reports on purification of the enzyme from liver are few. Geddes \& Hunter (1928) and Euler (1961) partially purified the enzyme from calf liver but did not provide purification and recovery data. Suld \& Hubert (1965) reported a 50-fold purification of guinea-pig liver asparaginase in low yield.

The biological properties of asparaginase may be considered in relation to its biochemical properties. The persistence of the guinea-pig serum enzyme in mouse plasma and the anti-lymphoma effect of chicken-liver asparaginase after repeated injections together suggest that the anti-lymphoma effect of the preparations is due to a decrease in the $I$ asparagine concentrations in tissues. This is supported by the observed reversal of the antitumour effect of guinea-pig serum asparaginase by orally administered asparagine. Inability to produce an anti-lymphoma effect by single injections of chicken-liver asparaginase, in amounts corresponding to the quantity of guinea-pig serum 
asparaginase that produces a significant antitumour effect, is probably due to its comparatively high clearance rate from mouse plasma, so that there is not sufficient time for it to act on the tumour cells. This appears to be the case also for the yeast enzyme (Broome, 1965).

The reason for the relatively high clearance rate of chicken-liver asparaginase after injection is not clear. Broome (1965) suggested that the rapid clearance of the yeast enzyme was associated with its high molecular weight. It seems unlikely in the present case that the difference between mol. wt. 210000 and mol. wt. 306000 could account for the different clerance rates of guinea-pig serum asparaginase and chicken-liver asparaginase. Further, we found a high molecular weight for the main asparaginase component of $E$. coli, and preparations of this enzyme are biologically active (Mashburn \& Wriston, 1964) and therefore presumably have a low clearance rate. Thus high molecular weight does not seem to be the sole cause of rapid clearance of asparaginases.

The $K_{m}$ values of guinea-pig serum asparaginase and chicken-liver asparaginase are very similar, indicating that the $K_{m}$ values could not be causally connected with anti-tumour properties. The $K_{m}$ of guinea-pig serum asparaginase reported by us is $7 \cdot 2 \times 10^{-5} \mathrm{M}$ in $0.05 \mathrm{M}$-borate buffer, $\mathrm{pH} \mathrm{8.5}$, and is not in agreement with the previously reported value of $2.2 \times 10^{-3} \mathrm{M}$ obtained by Tower et al. (1963) in the same buffer at $\mathrm{pH} 7.5$ and 9.3. There is no explanation for this discrepancy. It seems unlikely that the value at $\mathrm{pH} 8.5$ should differ so much from those at $\mathrm{pH} 7.5$ and 9.5. However, from a biological point of view, the value of Tower et al. (1963) seems an improbable one, if $K_{m}$ is compared with normal substrate concentrations in vivo. The serum asparagine contents reported in man and in the cat are $4.4 \times 10^{-5} \mathrm{M}$ and $6.8 \times 10^{-5} \mathrm{M}$ respectively, calculated from data from Stein \& Moore $(1954 a, b)$. If these values are applicable to mice, substrate deamination in vivo by the administered enzyme should take place extremely slowly; thus our $K_{m}$ value of $7.2 \times 10^{-5} \mathrm{M}$ may be the more likely one in view of the biological effects of the enzyme, which appear to rest on asparagine removal.

The possibility of using enzymes as chemotherapeutic drugs has been suggested (Bergel, 1961), but one of the main criticisms frequently levelled against the use of enzymes in cancer chemotherapy is that large foreign protein molecules may rapidly be taken up by reticuloendothelial systems, often coupled with immunological rejection. The relation between guinea-pig serum asparaginase and host mouse is such, however, that after repeated injection enzyme activity remains high in the blood stream of the mouse for a prolonged period. The results presented strongly suggest that the search for suitable enzyme sources should be based on their rate of clearance in vivo rather than on availability.

Aspartic acid hydrazide is a competitive inhibitor of asparaginase, and its anti-tumour properties have been confirmed. The latter may be due to the antimetabolite affecting the availability of asparagine, rather than to inhibition of endogenous asparaginase.

We thank Dr J. D. Broome, Department of Pathology, New York University Medical Center, for supplying us with 6C3HED lymphoma and for most helpful discussions. We gratefully acknowledge collaboration and biological advice by Dr M. E. Whisson and materials from Glaxo Laboratories, Greenford, Middlesex, and from Dr Roy Wade. The work was supported by grants to the Chester Beatty Research Institute, Institute of Cancer Research: Royal Cancer Hospital, from the Medical Research Council and the British Empire Cancer Campaign for Research, and by Research Grant no. CA-03188-08 from the National Cancer Institute, U.S. Public Health Service. T. O. held a World Health Organisation Research Grant during the period of the research.

\section{REFERENCES}

Ainis, H., Kurte, H. M., Kraemer, P. I., Weiner, H. E., Ryan, R. M. \& Jameson, E. (1958). Cancer Res. 18, 1309. Andrews, P. (1965). Biochem.J.96,595.

Andrews, P., Bray, R. C., Edwards, P. \& Shooter, K. V. (1964). Biochem.J. 93, 629.

Applemans, F., Wattiaux, R. \& de Duve, C. (1955). Biochem.J.59, 438 .

Bergel, F. (1961). Chemistry of Enzymes in Cancer, pp. 56, 60. Springfield, Ill.: C. C. Thomas.

Bergel, F. \& Bray, R. C. (1959). Biochem.J.73, 182.

Boyse, E. A., Old, L. J. \& Stockert, E. (1963). Nature, Lond., 198, 800.

Broome, J. D. (1961). Nature, Lond., 191, 1114.

Broome, J. D. (1963a). J.exp. Med.118,99.

Broome, J. D. (1963b). J. exp. Med.118, 121.

Broome, J. D. (1965). J. nat. Cancer Inst. 35, 967.

Campbell, H. A., Old, L. J. \& Boyse, E. A. (1964). Proc. Amer. Ass. Cancer Res. 5, 10.

Clementi, A. (1922). Arch. int. Physiol.19, 369.

de Duve, C., Pressman, B. C., Gianetto, R., Wattiaux, R. \& Applemans, F. (1955). Biochem.J. 60, 604.

Dixon, M. \& Webb, E. C. (1964). Enzymes, 2nd ed., p. 329. London: Longmans, Green and Co.

Euler, H. von (1961). Ark. Kemi,17, 267.

Geddes, W. F. \& Hunter, A. (1928). J. biol. Chem. 77, 197. Gilbert, D. A. \& Bergel, F. (1964). Biochem.J. 90, 350.

Gomori, G. (1955). In Methods in Enzymology, vol. 1, p. 138. Ed. by Colowick, S. P. \& Kaplan, N. O. New York: Academic Press Inc.

Grassmann, W. \& Mayr, O. (1933). Hoppe-Seyl. Z. 214, 185.

Herbert, P. A., Kraemer, W. H. \& Pillemer, L. (1958). Blood, 13, 732.

Jameson, E., Ainis, H. \& Ryan, R. M. (1956). Science, 124, 980.

Jameson, E., Ainis, H. \& Ryan, R. M. (1958). Cancer Res. 18,866 . 
Kidd,J. G. (1953a). J.exp. Med. 98,565.

Kidd,J. G. (1953b). J.exp. Med.98, 583.

Konitzer, K. \& Voigt, S. (1963). Clin. chim. Acta, 8, 5 .

Kretovich, W. L. (1958). Advanc. Enzymol.20,319.

Kwak, K. S., Jameson, E., Ryan, R. M. \& Kurtz, H. M. (1961). Cancer Res.21, 44.

Lang, S. (1904). Beitr.chem. Physiol.Path.5, 320.

Manning, G. B. \& Campbell, L. L., jun. (1957). Canad. J. Microbiol.3, 1001.

Markham, R.(1942). Biochem.J.36, 790.

Mashburn, L. T. \& Wriston, J. C., jun. (1963). Biochem. biophys. Res. Commun.12,50.

Mashburn, L. T. \& Wriston, J. C., jun. (1964). Arch. Biochem. Biophys. 105, 450.

Meister, A., Levintow, L., Greenfield, R. E. \& Abendschein, P. A. (1955). J. biol. Chem. 215, 441,
Michelson, M. N. \& Flippin, R. S. (1958). J. nat. Cancer Inst. 20, 495.

Ohnuma, T. (1965). Ph.D. Thesis: University of London. Roper, J. A. \& McIlwain, H. (1948). Biochem. J. 42, 495.

Russel, J. A. (1944). J.biol. Chem.156, 457.

Shibata, K. (1904). Beitr.chem.Physiol.Path.5, 384.

Singer, T. P. \& Kearney, E. B. (1950). Arch. Biochem. 29, 190.

Stein, W. H. \& Moore, S. (1954a). J. biol. Chem. 211, 915.

Stein, W. H. \& Moore, S. (1954b.) J. biol. Chem. 211, 927.

Suld, H. M. \& Hubert, P. A. (1965). J. biol. Chem. 240, 2234.

Tower, D. B., Peters, E. L. \& Curtis, W. C. (1963). J. biol. Chem. 238, 983.

Warburg, O.\& Christian, W. (1942). Biochem.Z.310,384.

Wu, R. \& Racker, E. (1959). J.biol. Chem. 234, 1029.

Yellin, T. O. \& Wriston, J. C., jun. (1966). Science, 151, 998. 